ISSN (print): 1698-6180. ISSN (online): 1886-7995

www.ucm.es/info/estratig/journal.htm

Journal of Iberian Geology 38 (1) 2012: 71-84

http://dx.doi.org/10.5209/rev_JIGE.2012.v38.n1.39206

\title{
Neotectonics of mainland Portugal: state of the art and future perspectives
}

\author{
Neotectónica de Portugal peninsular: estado de la cuestión y perspectivas de futuro
}

\author{
J. Cabral \\ LATTEX / IDL, Faculty of Sciences, Lisbon University, Ed. CS, 2o Piso, Campo Grande 1749-016 Lisboa, Portugal. \\ jcabral@fc.ul.pt.
}

Received: 19/04/2011 / Accepted: 29/02/2012

\begin{abstract}
This paper presents a synthesis of the neotectonic studies performed in mainland Portugal that address the "recent" (post Piacenzian, $\sim 3 \mathrm{Ma}$ ) tectonic evolution of the Portuguese territory as part of the West Iberian continental margin, specifically in regard to regional seismic hazard evaluation. The interaction of the Iberian microplate with the Nubia plate is identified as the source for the regional neotectonic deformations, which occur at relatively low rates in spite of significant historical seismic activity. In this context of low strain rates expressed by the presence of slow slip rate active faults, it is important to acquire paleoseismic data on the major seismogenic structures to characterize the large earthquakes that they generated in the past, because average recurrence intervals are much longer than the time span covered by the regional historical and instrumental period.
\end{abstract}

Keywords: Neotectonics, Seismotectonics, Active faults, Seismic Hazard, Portugal

Resumen

Este artículo presenta una síntesis sobre los trabajos de neotectónica que se han llevado a cabo en el Portugal continental como parte del margen continental Iberico occidental, que se centren en la evolución tectónica "reciente" (post Plasenciano, 3 Ma), en especial aquellos que se centran en la evaluación del peligro sísmico regional. La interacción entre la microplaca Ibérica y la placa de Nubia se caracteriza por ser una fuente de deformaciones neotectónicas que ocurren a velocidades relativamente bajas a pesar de que la sismicidad histórica es significativa. En este contexto de tasas de deformación bajas, reflejadas por la presencia de fallas lentas, es importante adquirir datos paleosísmicos en las principales fallas sismogénicas para así caracterizar los terremotos catastróficos que hayan podido producir-se en dichas estructuras en el pasado. Esto es especialmente importante dado que los períodos de recurrencia de dichas fallas son mucho más largos que el periodo de tiempo cubierto por los datos sísmicos históricos o instrumentales.

Palabras clave: Neotectónica, Sismotectónica, Fallas activas, Peligro sísmico, Portugal. 


\section{Regional setting}

Portugal mainland is located on the Eurasian Plate, close to the West-Iberian continental margin and the Eurasia-Nubia plate boundary (eastern sector of the Azores - Gibraltar fracture zone). The regional geodynamics has been driven by the NW-SE convergence of Eurasia and Nubia, which has occurred at this longitude at an average rate of $4-5 \mathrm{~mm} / \mathrm{yr}$ for the past $3 \mathrm{Ma}$, according to the global geological models of plate motions (NUVEL-1A by DeMets et al., 1994, and the more recent MORVEL by DeMets et al., 2010). Space-geodetic observations indicate a significantly different instantaneous interplate motion, with displacement vectors of Eurasia-Nubia rotated anticlockwise relatively to the NW direction of geological models and suggesting a slowing of the convergence rate (Calais et al., 2003; Fernandes et al., 2003; Nocquet and Calais, 2004), though the discrepancy between the geological and GPS data has been reduced in the MORVEL model.

The Eurasia-Nubia plate boundary is clearly discernable at the western and central parts of the Azores - Gibraltar fracture zone, represented by the Terceira Ridge leaky transform, near the Azores archipelago, and by the Gloria transform fault, eastwards up to the Tore Madeira Rise $\left(\sim 20^{\circ} \mathrm{W}\right)$. East of the Gloria fault, the plate boundary is poorly established and its nature is matter of debate, as the interplate deformation is apparently distributed across a broad area, over $200 \mathrm{~km}$ wide.

Since the late 1990s, a large amount of multi-channel seismic reflection data, along with high-resolution multi-beam swath bathymetry data, have been acquired in the SW Iberian margin in an effort to locate a discrete plate boundary in the Gulf of Cadiz area and, at the same time, to try to identify the source of the great 1755 Lisbon earthquake (estimated $\mathrm{M}_{\mathrm{w}}$ 8.5-8.7; Johnston, 1996; Martinez-Solares and López Arroyo, 2004). Several studies (e.g. Zitellini et al., 1999, 2001, 2004; Gràcia et al., 2003; Terrinha et al., 2003) revealed a complex structural pattern, with discrete active reverse faults trending NESW to NNE-SSW, such as the Gorringe Bank, Marquês de Pombal and Horseshoe faults. There are also E-W to WNW-ESE faults, such as the Guadalquivir Bank and Portimão Bank faults. Multiple rupture on these faults was proposed as a possible source of the 1755 earthquake (Gràcia et al., 2003; Baptista et al., 2003).

Coeval $\sim \mathrm{E}-\mathrm{W}$ extension in the Alboran Basin at a rate of $\sim 2 \mathrm{~mm} / \mathrm{yr}$ (Serpelloni et al., 2007), and left-lateral shear along the NNE trending Trans-Alboran shear zone, are not straightforward in the context of regional shortening, indicating complexity of deformation at the plate borders.
In this context, and based upon a number of independent observations such as detailed seafloor morphology, earthquake distribution and seismic profiles (multi-channel reflection, as well as wide angle refraction), Gutscher and others (e.g. Gutscher, 2004; Gutscher et al., 2002, 2009) proposed the occurrence of active subduction in the Gibraltar Arc by westward roll-back of an old (Miocene?) plate. In a recent paper, Pedrera et al. (2011) question this model, defending that the eastward Gibraltar Arc oceanic subduction system is inactive probably since the Late Miocene. According to these authors, the current tectonic framework in the Gibraltar Arc domain is of continental collision, with the regional intermediate seismicity being associated to part of the old, $\mathrm{N} 30^{\circ} \mathrm{E}$ to $\mathrm{N} 40^{\circ} \mathrm{E}$ oriented subducted slab, orthogonal to the regional convergence.

New high-resolution multi-beam bathymetry data allowed the recognition of several WNW-ESE trending lineaments in seafloor sediments of the Gulf of Cadiz, and the interpretation of multi-channel seismic reflection profiles showed that they are controlled by underlying deep seated faults (Rosas et al., 2009). Based upon the morphology associated with two of the lineaments and on analogue modelling, the authors conclude that these lineaments correspond to the bathymetric expression of ongoing right-lateral strike-slip reactivation of WNWESE pre-existing faults, and estimate an age of ca. $1.8 \mathrm{Ma}$ for this tectonic reactivation. Zitellini et al. (2009) extend these lineaments farther west, across the Horseshoe abyssal plain and up to the Hirondelle Seamount; theses authors also interpret them as faults (the SWIM faults) and propose that this newly found set of almost linear and sub parallel, WNW-ESE trending vertical faults that form a narrow band of deformation over a length of $600 \mathrm{~km}$, corresponds to the present Nubia-Europe plate boundary in this region.

The level of seismotectonic activity at the West-Iberian continental margin points to an atypical passive margin. An explanatory model argues that this margin is in transition from passive to active convergence (Ribeiro et al., 1996; Ribeiro, 2002). According to this model, Iberia is behaving as a microplate that is rotating clockwise between Africa and Eurasia, inducing convergence across the West Iberia margin at $\sim 1 \mathrm{~mm} / \mathrm{yr}$.

As a result of the regional geodynamic setting, mainland Portugal and the nearby Atlantic area experiences moderate levels of seismicity, characterized by relatively frequent $\mathrm{M}<6$ events and the occurrence of occasional large earthquakes, such as the $1969 \mathrm{M}_{\mathrm{S}} 7.9$ (Fukao, 1973) and $2007 \mathrm{Mw} 6.0$ (Stich et al., 2007) Horseshoe events, in addition to the more sporadic very large events, such as the 1755 "Lisbon earthquake". 


\section{The Neotectonic studies in mainland Portugal}

\subsection{The early years}

Geological studies in Portugal started in the mid $19^{\text {th }}$ century and evolved rapidly; the first draft of the Geological Map of Portugal (1:500,000 scale) was prepared by Carlos Ribeiro and Nery Delgado in 1867, and published in 1876. Early geological studies already included structural characterization, and the structural/tectonic view was notably implemented in the late $19^{\text {th }}$ to early $20^{\text {th }}$ centuries, by Nery Delgado and Paul Choffat, superbly expressed in the study of the Arrábida Chain (south of Lisbon) (Choffat, 1908).

Paul Choffat was interested in the 1755 earthquake and in the relatively intense seismic activity from the second half of the $19^{\text {th }}$ century to early $20^{\text {th }}$ century (e.g. Choffat, 1904), which included the 1858 "Setúbal earthquake", referenced in Johnston and Kanter (1990) as one of the largest earthquakes ever registered worldwide in "stable continental crust", with estimated $\mathrm{M}_{\mathrm{w}}$ 7.1. In that publication Choffat cited and discussed the intensity distribution of the 1755 and 1858 earthquakes, and of other felt events that occurred in 1903.

On April $23^{\text {rd }}, 1909$ a violent earthquake took place in the Lower Tagus river valley $\left(\mathrm{M}_{\mathrm{w}}=6.0\right.$ to 6.2 ; TevesCosta et al., 1999; Dineva et al., 2002; Stich et al., 2005) causing significant damage and 46 fatalities. The town of Benavente, located about $30 \mathrm{~km} \mathrm{NE}$ from Lisbon on the eastern bank of the Tagus River, was completely destroyed, and other nearby villages were intensely affected (Teves Costa and Batlló, 2010). The occurrence of this event increased interest in the regional seismic activity. The effects of the earthquake were studied by Bensaúde (1910) and Choffat and Bensaúde (1911) who published a comprehensive report. Reference to a geological origin was already considered, as Bensaúde (1910) refered to two probable seismogenic faults as potential sources (Tagus and Sorraia faults), and Dinis (1911) also indicated faults as the source of the "tectonic earthquakes". He proposed that the 1909 event was generated by a "vertical movement" along a NE-SW "line" passing through Benavente.

The following years were marked by a relative stagnation of geological research in Portugal, and particularly of studies with tectonic implications. Some exceptions were the monumental work by Pereira de Sousa (19191932) on the 1755 earthquake, or the works by Freire de Andrade $(1933,1937)$ on the offshore submarine valleys, and by Zbyszewski (1939) regarding the Sado Cenozoic Basin (south of Lisbon). This author refered to significant Pliocene-Quaternary tectonic activity (vertical move- ments, tilting and faulting).

In the 1940-50's, however, there was a resumption of geological studies addressing "recent" Pliocene to Quaternary tectonic deformations, as exemplified in the works by Teixeira (1944) on the "Plio-Pleistocene tectonics" of NW Iberia, or by Zbyszewski $(1948,1959)$ concerning "Pliocene salt tectonics in Portugal". This latter author also mentioned several examples of Quaternary tectonic deformations in a synthesis on the "Quaternary of Portugal" (Zbyszewski, 1957). This period corresponds to a renewal of physical geography, and the geomorphology of Portugal was addressed by several geographers who introduced a mobilist view of landscape evolution, relating it with "recent" tectonics and, tentatively, with regional seismicity (e.g. Birot, 1945, 1949; Feio, 1949, 1951a,b; Ribeiro, 1942, 1943, 1949).

\subsection{The modern years: 1960 to Present}

In the period 1960-80, structural geology and tectonics developed as autonomous disciplines in Portugal. The first modern regional structural study was produced (Ribeiro, 1974), and the introduction of plate tectonics theory allowed for the interpretation and understanding of the present regional tectonic framework. Meanwhile, new techniques in geophysics were also developed, and the national seismic network increased from 3 to 12 analogue stations after the 28th February 1969, $\mathrm{M}_{\mathrm{w}} 7.8$ earthquake (Fukao, 1973), allowing better coverage of the regional seismicity and an improved appraisal of its distribution.

The first reference to "neotectonics" in the Portuguese literature appears in Ribeiro et al. (1979), meaning postMiocene tectonics. A first, small scale, Neotectonic Map of Portugal, showing faults with evidence of "activity in the Quaternary", was published two years later in the scope of a work on geothermal analysis (Ribeiro and Moitinho de Almeida, 1981). However, systematic neotectonic research, specifically oriented to hazard assessment, was initially promoted in the scope of nuclear power plant siting studies in mainland Portugal, sponsored by the Portuguese Electricity Company (Electricidade de Portugal, EDP) and by the Portuguese nuclear regulatory entity (Gabinete de Protecção e Segurança Nuclear, GPSN).

The intention of building a nuclear power plant at the Ferrel site (W coast) led to a detailed neotectonic study of the area, following the criteria of the United States Nuclear Regulatory Commission (USNRC, 1978). The work started in 1979 focused on the characterization of the activity of a local fault (Ferrel fault), including geological mapping at the 1:2,000 scale (Cabral, 1981). The first 
trench for paleoseismic research in Portugal was then opened, and the Ferrel site was abandoned partly due to the trenching results, which showed evidence of Quaternary activity (Cabral and Ribeiro, 1981, 1986).

J. Cabral, formerly at GPSN, joined A. Ribeiro at the Geology Department of the Faculty of Sciences of Lisbon University (FCUL) in 1982, and started the neotectonic study of NE Trás-os-Montes (NE Portugal) under his supervision (Cabral, 1985). This study, though performed in the scope of a post-graduate thesis, was stimulated by the intention of Spain of building a nuclear plant at Sayago and, later, of implementing project IPES (Instalación Piloto Experimental Subterráneo) at Aldeadavila, near the Trás-os-Montes border (Barriga et al., 1988).

Neotectonic research by the Lisbon University team was intensified in 1983, in the scope of new nuclear power plant site selection studies promoted by EDP and GPSN. Studies included regional and detailed research in different areas of Portugal, with an emphasis on major fault zones, e.g. the Lower Tagus fault zone (Cabral et al., 1984), the Ponsul fault (Dias and Cabral, 1989), and the Vilariça fault (Cabral, 1989). The results were synthesised in a Neotectonic Map of Mainland Portugal (1:1,000,000 scale) (Cabral and Ribeiro, 1988, 1989), showing "faults with evidence of activity in the last $2 \mathrm{Ma}$ ". Data were later updated in a Ph.D. thesis (Cabral, 1993) and published in a memoir (Cabral, 1995), and a compilation and interpretation of present stress indicators in the study region was accomplished (Ribeiro et al., 1996).

Further studies performed by the Lisbon University group and by other teams in the scope of research projects, M.Sc. and Ph.D. theses, have largely increased the knowledge on the active structures in the Portuguese mainland. Many examples may be given, such as for the Penacova-Régua-Verin fault (Baptista, 1998), the PortoCoimbra-Tomar fault zone (Dinis, 2004; Dinis et al., 2007; Gomes, 2008), the Lower Tagus Valley fault system (Vilanova, 2003; Vilanova and Fonseca, 2004; Cabral et al., 2003, 2004, 2011a,b; Besana-Ostman et al., 2012; Carvalho et al., 2006, 2008; Martins et al., 2009), the Vidigueira-Moura and Alqueva faults (Brum da Silveira, 2002; Brum da Silveira et al., 2009), or faults in the Algarve (southern Portugal) (Dias, 2001; Dias and Cabral, 2002a,b).

\section{Methodology and data}

As stated above, it is after the early 1980s that the research team from Lisbon University performed studies directed at the neotectonics in mainland Portugal, intended as the study of tectonic deformations occurring since the initiation of the current tectonic regime, characterized by a NW-SE trending $\mathrm{S}_{\mathrm{H} \max }$ that results from the IberiaNubia convergence along the same azimuth (Ribeiro et al., 1996, Borges et al., 2001).

The timing of onset of the current stress regime is not easy to determine, however, as its orientation is not clearly distinct from the roughly NNW-SSE late Miocene (to early Pliocene?) compressive stress field (Ribeiro et al., 1990; Cunha et al., 2000, 2009). What the geological registry shows is that, where present, Pliocene sediments of Piacenzian age (3.6-2.58 Ma) postdate an intense postTortonian (upper Miocene) shortening phase. On the other hand, these and younger sediments of probable Gelasian age (2.58-1.8 Ma, lower Quaternary) that constitute the top of the sedimentary infill in the former Miocene compressive basins are affected by displacement along major faults and show evidence of having been uplifted, suggesting a resumption of the tectonic activity in the Quaternary, making this period $(\sim 2.6 \mathrm{Ma})$ an adequate time frame for the Neotectonic period in mainland Portugal.

The considered neotectonic activity spans a large time interval, based on the current tectonic regime (upper Pliocene to Present), thus requiring the use of relatively old stratigraphic and geomorphic references to recognize and characterize the deformations accumulated since the onset of the neotectonic period - typically fluvial sediments that predate the Quaternary entrenchment of the regional drainage network and correlative raised marine sediments and abrasion platforms, of Piazencian age, along the littoral.

Even though this time window is quite wide comparatively to other periods of neotectonic activity considered for more active regions, it is appropriate for the current geodynamical setting of the Portuguese mainland, where the active faults have slow slip rates and long seismic cycles. It is thus intended to assure the identification of all the potentially hazardous seismogenic sources, including those that take a long time to accumulate geomorphic and/or stratigraphic evidence of activity. It is the same time frame used in the Quaternary Active Faults Database of Iberia (QAFI), where it was chosen for similar reasons (García-Mayordomo et al., 2010).

The neotectonic deformations include two major interrelated components that may be distinguished and independently analysed for methodological purposes: vertical movements of the lithosphere, resulting from large scale folding and isostatic adjustments, and active faulting.

\subsection{Vertical movements of the crust}

Evidence for almost generalized uplift of the Portuguese mainland territory since the end of the Pliocene 
is given by the common presence of high sea cliffs and raised marine terraces along the coast, and of a deeply incised drainage network inland (Figs. 1 and 2).

An indirect methodology was thus used for the characterization of the neotectonic vertical movements in the study region, consisting in the recognition of geological and geomorphologic references whose relation to the coeval sea level is reasonably known, so that the primitive height at which they were formed can be estimated and compared with their present elevation (Fig. 3).

This methodology is more rigorous and easier to apply in the coastal area due to the proximity to the reference datum (mean sea level) and the possibility of using directly correlatable geological and geomorphologic markers (marine terraces and abrasion platforms). The existence of several terrace levels at one particular coastal area is evidence for long-term vertical movements affecting the coast. The rationale is that the relict shorelines record both fluctuating Quaternary sea-level highstands and the ongoing tectonic uplift. Worldwide data of Quaternary sea-level changes have been combined to build eustatic sea-level curves that can be used as references for research studies (e.g. Shackleton et al., 1984; Haq et al., 1987; Dowsett and Cronin, 1990; Naish and Wilson, 2009; Raymo et al., 2011, for the late Pliocene-early Pleistocene sea-level, and Shackleton and Opdyke, 1973; Bloom et al., 1974; Chappell, 1974; Bender et al., 1979; Bloom, 1980; Chappell and Shackleton, 1986; Siddall et al., 2006, among others, for the Pleistocene eustatic sealevel curves).

The rates of uplift can be quantified by correlation of inner edge elevations (which approximate mean sea level at the time of formation) to sea-level highstands. If the elevation and age of these sea-level highstands are known, then the uplift rate can be calculated for each marine terrace.

In what concerns mainland Portugal, several sectors of the coastal area present a discontinuous series of variably wide, although predominately narrow, upper Pliocene to Quaternary marine terraces and/or wave-cut platforms located at altitudes ranging from near present sea level to a few hundreds of meters. When preserved, the terrace sediments are generally thin, commonly composed of a lower pebbly layer overlain by beach sands, rarely containing shells and fragments of marine fossils, and often buried by eolianites and/or colluvial deposits of sand and gravel from the adjacent paleo-sea cliffs. Taking the elevation and estimated age of beach sediments and/or correlative abrasion platforms at several places (200-350 m, attributed to the Piacenzian, $3 \mathrm{Ma} ; 70-80 \mathrm{~m}$, attributed to the Lower Pleistocene, $\sim 1 \mathrm{Ma} ; 35-40 \mathrm{~m}$, attributed to MIS 7, 200-250 ka; and 20-25 m, attributed to MIS 5e, $\sim 125 \mathrm{ka}$ ), relatively constant, long to shorter term average uplift rates of 0.1-0.2 mm/yr are inferred. Detailed studies of vertical movements of the crust based upon raised marine terraces are presently being performed for the southwestern region of mainland Portugal and the preliminary results yielded similar uplift rates for the Upper Pleistocene (Figueiredo et al., 2011). Major uncertainties rely upon the coeval eustatic sea levels, the constraining of the paleo-shore lines and of their present elevation, and the age of the littoral references.

Inland, away from the coast and from direct connection to sea level as the reference datum, erosion surfaces and sediments of exoreic fluvial origin were used as markers for inferring the regional vertical movements. In mainland Portugal, the valleys of the major rivers typically show flights of downward-stepping terraces with variable sedimentary fills, documenting long periods of valley incision that alternate with shorter periods of predominantly lateral erosion and minor aggradation. In this context, the rationale is that the fluvial terraces may serve as references to evaluate rates of fluvial incision at the long term, which is considered a reasonable proxy for regional uplift (e.g. Merrits et al., 1994; Burbank and Anderson, 2001; Hancock and Anderson, 2002).

When using the river terraces, uncertainties are higher than for the littoral references, as besides the common uncertainties in the age of the references and in the contemporary base level, there is the interference of climatic factors on river erosion and sedimentation, and variable river gradient, as well as the capacity of response of the river to the main external controlling mechanisms (tectonics, climate and sea-level). In fact, it is assumed that the elapsed time is long enough for the river to incise and regularize its longitudinal profile to the lowering base level that results from the continental uplift, that is, it is assumed that the incision rate balances the uplift rate of the continent. As Burbank and Anderson (2001) stressed, it must also be assumed that the longitudinal gradient of the modern and ancient valley floors were similar, and differences in former and present base levels small comparatively to the amount of uplift. River incision is thus more appropriate for long term evaluation of the continental uplift, except in the river-mouth areas, where the response to relative sea-level change is rapid.

The long term uplift rates obtained for the inland areas, averaged for the last $\sim 3 \mathrm{Ma}$, are in general similar to those inferred for the littoral (0.1-0.2 mm/yr) (Cabral, 1995; Cunha et al., 2005, 2008, 2010). We may conclude that the uplift rates estimated for the Portuguese mainland are low comparatively to uplift rates recognized in other regions subjected to active tectonics, although the rates obtained at the coastal region are high comparative- 

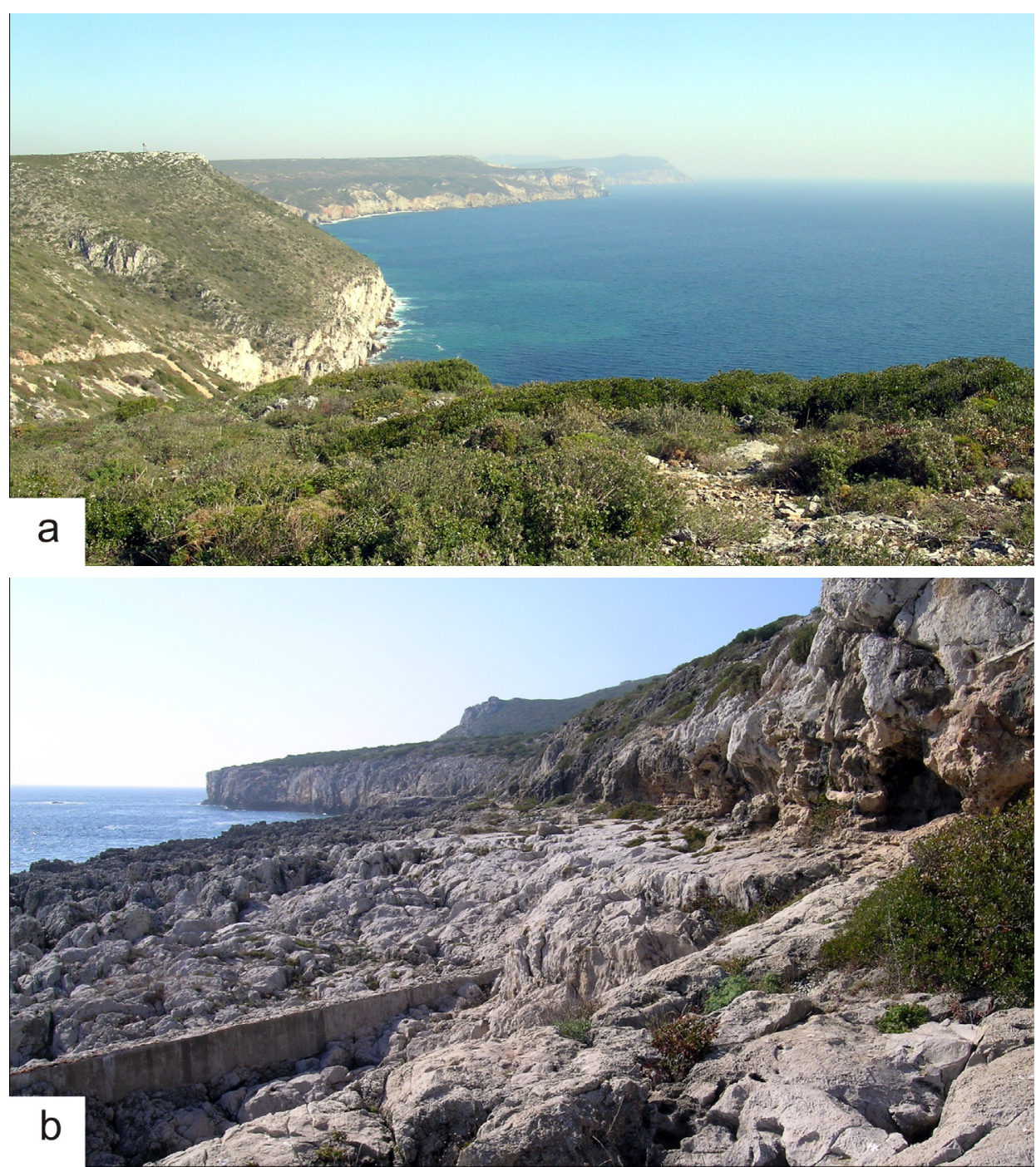

Fig. 1.- a - View towards the east of the high sea-cliffs bounding the Miocene Arrábida fold and thrust belt, located to the south of Lisbon. The erosion surface at the top is at $\sim 200 \mathrm{~m}$ a.s.l. and truncates folded Jurassic limestones; it post dates the Tortonian folding, though its age is still poorly constrained; $b$ - View towards the west of a raised marine terrace located at $\sim 10 \mathrm{~m}$ a.s.l. at the foot of the former sea-cliffs; the age of this rocky platform, with some beach sands and eolianites still preserved, is matter of debate, as radiocarbon dates obtained for sea-shells from the sediments yield ages close to $35 \mathrm{ka}$ (Ramos Pereira et $a l .$, 2007), implying abnormally high uplift rates to explain the present elevation.

Fig. 1.- Vista hacia el este de los acantilados que limitan el pliegue y el cinturón de cabalgamientos Miocenos de la Arrabida, situados al sur de Lisboa. La superficie de erosión a techo tiene una altura de $200 \mathrm{~m}$ y trunca calizas Jurasicas plegadas. Dicha erosión es posterior al plegamiento Tortoniense aunque su edad es poco conocida. $b$ - Vista hacia el oeste de la terraza marina levantada situada a $10 \mathrm{~m}$ del nivel del mar, al pie de los antiguos acantilados. La edad de esta plataforma rocosa, con arenas de playa y eolianitas preservadas, está en discusión dado que las dataciones radiométricas de caparazones marinos en sedimentos aportan una edad de 35 ka (Ramos Pereira et al., 2007), lo que implica unas tasas de levantamiento anómalamente altas. ly to other passive continental margins. A synthesis of the vertical movements in the last $3 \mathrm{Ma}$ (upper Pliocene and Quaternary) is presented in Figure 4, showing overall uplift, higher in the northern sector.

\subsection{Active faults}

Besides the vertical deformations of the crust, neotectonic activity in mainland Portugal is also expressed by
Fig. 2.- Upstream view, towards the west, of the Douro River valley near S. João da Pesqueira (NE Portugal) showing the deep entrenchment of the river, which flows at $\sim 90 \mathrm{~m}$ a.s.l., incised on the bordering plateaus at an elevation of 500-600 m.

Fig. 2.- Vista, aguas arriba (hacia el W), del río Duero cerca de S. João da Pesqueira (NE Portugal) mostando profundo encajamiento. El flujo se produce $\sim 90 \mathrm{~m}$ por debajo de las mesetas colindantres, con una elevación de 500-600 m.

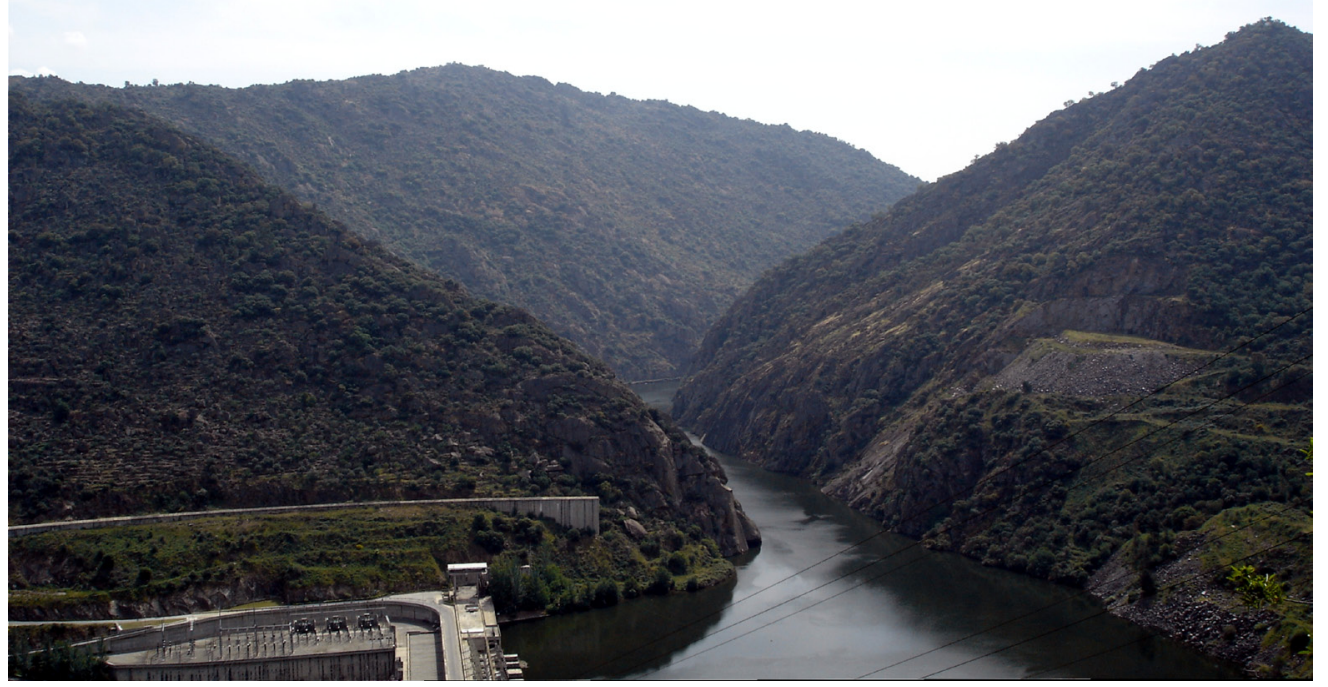




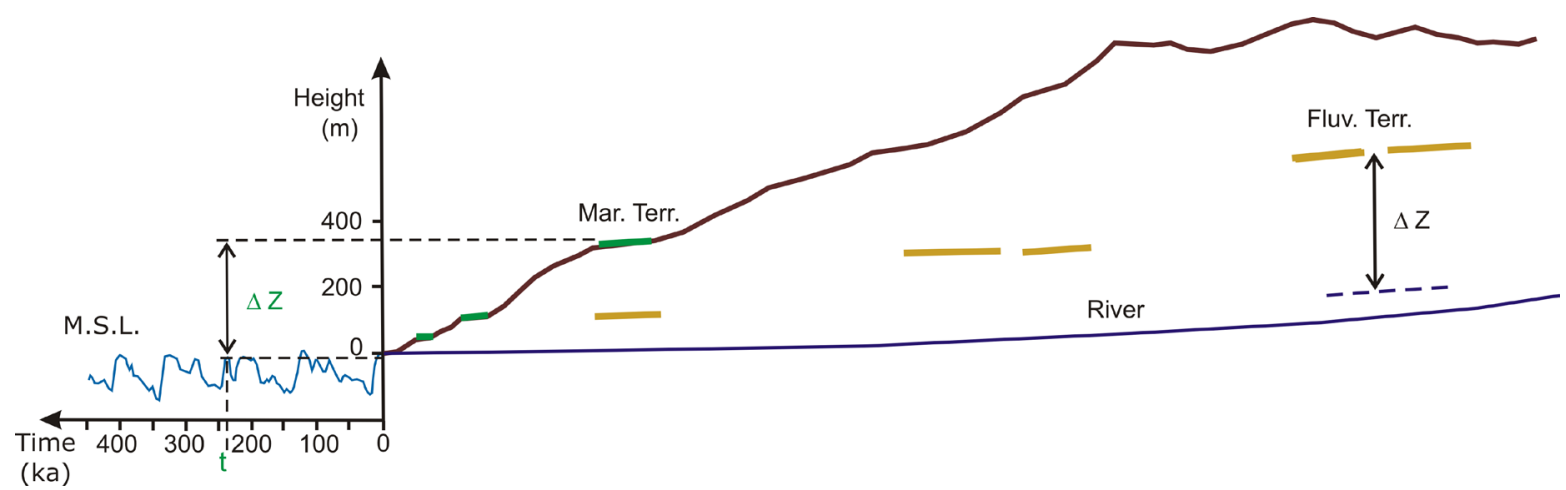

Fig. 3.- Schematic drawing to illustrate the methodology used for the characterization of the neotectonic vertical movements in mainland Portugal. (Fluv. Terr., fluvial terrace; Mar. Terr., marine terrace; M.S.L., eustatic mean sea level; eustatic sea level curve adapted from Siddal et al. (2005). Uplift $=\Delta Z$; uplift rate $=\Delta Z /$ age of reference).

Fig. 3.- Esquema que ilustra la metodología usada para la caracterización de los movimientos neotectónicos verticales en Portugal continental. Fluv. Terr., terraza fluvial; Mar. Terr., terraza marina; M.S.L., elevación media del nivel del mar; curva eustática del nivel del mar adaptada de Siddal et al. (2005). Levantamiento $=\Delta \mathrm{Z}$; tasa de levantamiento $=\Delta \mathrm{Z} /$ edad de referencia.

the occurrence of active faults, that is, of faults evidencing slip in the current tectonic regime so that recurrent movements are expectable in the (relatively) near future. As discussed above, for the study region this means faults evidencing movements in the Quaternary (past 2.5 Ma).

Active faulting was strongly conditioned by reactivation of pre-existent structures under a NW-SE compression, namely Variscan faults in the Paleozoic basement that had already been reactivated in previous deformational phases of the Alpine orogenic cycle, faults in Mesozoic extensional basins, and faults in Tertiary compressive and strike-slip basins, often rendering neotectonic reactivation difficult to distinguish from previous Neogene faulting which occurred in a rather similar stress field.

The criteria used for recognizing fault activity comprised structural/stratigraphic cross-cutting evidence and geomorphologic evidence. The first consisted of identifying faults affecting sediments dating from the neotectonic period considered, thus requiring the presence of sediments of Quaternary age. A major problem is that widespread erosion induced by uplift, low sedimentation and slow slip rates make "young" (Upper Pleistocene to Present) faulted sediments rare, so that cross-cutting evidence for recent activity is almost totally absent. The sediments affected by neotectonic faulting are usually deficiently dated and generally attributed to the upper Pliocene-lower Quaternary, thus proving evidence only for the longer term $(\sim 2.5 \mathrm{Ma})$ activity.

The geomorphologic criterion used to assess activity is the faults' morphotectonic expression; faults with preserved scarps, or faults producing river deflections, or deforming terraces and other reference surfaces of Quaternary age are considered active. A major problem in the application of this criterion consists in the difficulty of differentiating geomorphic features that effectively point to youthful activity, from other very similar features that result from erosional effects related to differential erosion between basement rocks and faulted Tertiary sediments, often preserved in tectonic basins that have been affected by intense exhumation due to the deep incision of through flowing, or nearby major rivers.

Fault activity in mainland Portugal shows a predominance of $\sim \mathrm{E}-\mathrm{W}$ to NE-SW faults with prevailing reverse movement component, and $\sim \mathrm{N}-\mathrm{S}$ to NNE-SSW faults with prevailing left-lateral strike-slip movement component, which were reactivated during the Quaternary under the action of a NW-SE $\mathrm{S}_{\text {Hmax }}$. Examples of the first set of structures are the north-verging Seia-Lousã fault (Cabral, 1995; Ribeiro et al., 1996; Sequeira et al., 1997) (Fig. 5a), that corresponds to the north boundary fault of the Portuguese Central Cordillera, the south-verging Ponsul fault (Dias and Cabral, 1989; Cabral, 1995; Cunha et al., 2005, 2008), located south of the Central Cordillera, and the Vidigueira-Moura fault (Brum da Silveira, 2002; Brum da Silveira et al., 2009), located in Alentejo (southern mainland Portugal). Examples of the second set of structures are the NNE-SSW Penacova-Régua-Verin and Manteigas-Vilariça-Bragança left-lateral strikeslip faults, located in northern Portugal (Baptista, 1998; Baptista et al., 1997, 1998; Cabral, 1989, 1995; Cunha and Pereira, 2000; Rockwell et al., 2009) (Fig. 5b).

As a result of the performed studies, a synthetic map of active faults in mainland Portugal (1:1,000,000 scale) was published in 1988 (Cabral and Ribeiro, 1988, 1989), revised in 1995 (Cabral, 1995), and successively updated (Fig. 6). Estimated long term ( 2.5 Ma) average slip rates range between 0.005 and $0.3-0.5 \mathrm{~mm} / \mathrm{yr}$, corresponding mostly to low activity rates. Thus, as referred above, "young" (Upper Pleistocene to Present) faulted 


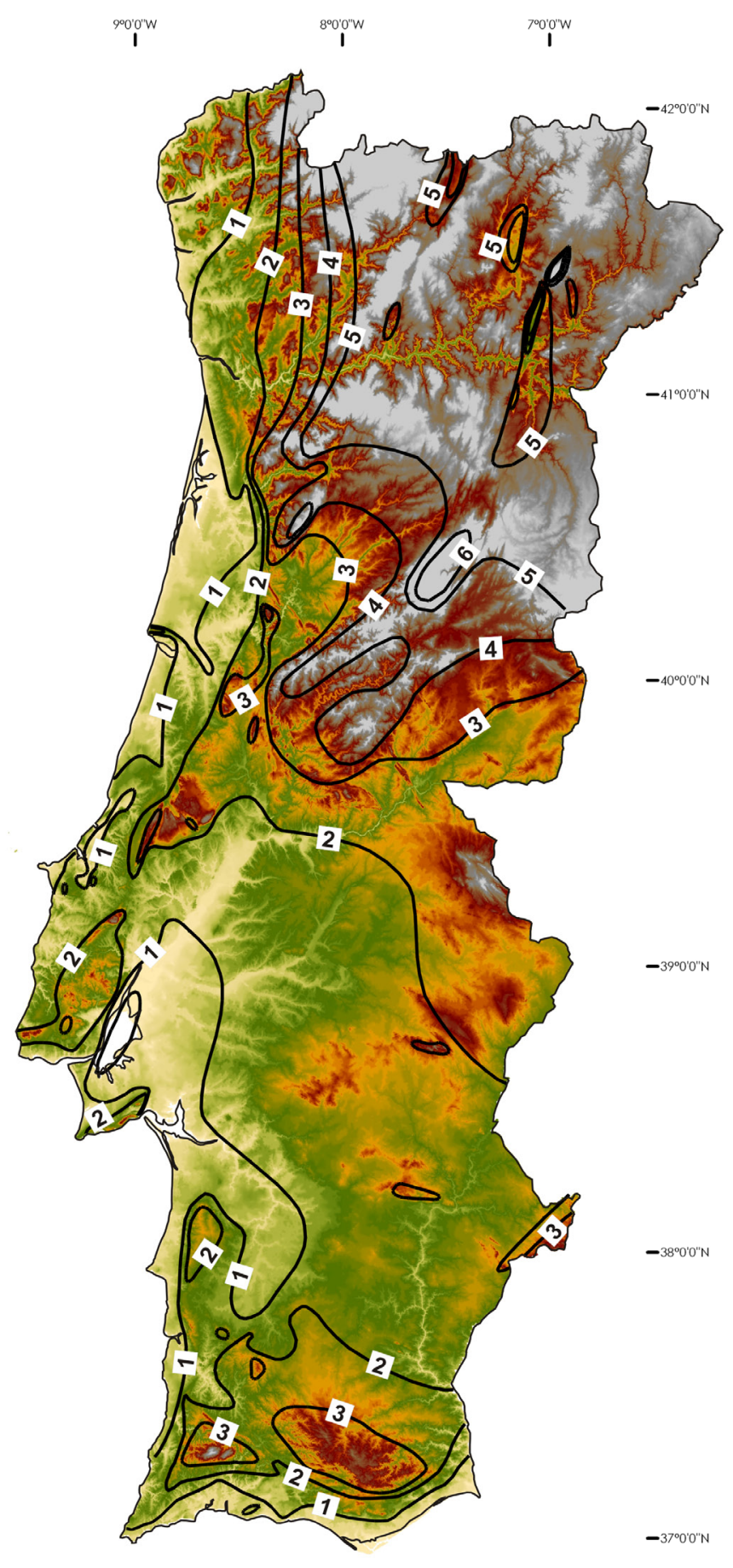

sediments are rare and, though some geomorphic features indicate youthful activity, most result from, or are enhanced by erosive effects due to the generalized fluvial entrenchment. The youngest documented deformation so far is along the Vilariça fault and dated at 15,000-10,000 years ago, obtained in the scope of paleoseismic studies performed by Rockwell et al. (2009).

\section{Present and futures perspectives}

In 2004, the research project "Seismotectonics GIS Database for Mainland Portugal" was implemented with the intention of promoting the revision, enlargement and integration of all the data pertaining to the Seismotectonics of the Portuguese mainland and adjacent area. The overall purpose was to construct a GIS database built upon the current European procedures envisaging its integration in a European database. The database included information on upper Pliocene-Quaternary crustal vertical movements, active fault geometry, kinematics, and seismogenic potential, archeoseismological records, stress indicators, and seismicity (Silva et al., 2008).

A review and update of all the information pertaining to the active faults in mainland Portugal was performed in the scope of that project, and it is presently being completed and inserted into larger databases of active faults, namely at the Iberian scale (Active Faults Database of Iberia, García-Mayordomo et al., 2010) and the European scale (SHARE European-scale seismic source model, Nemser et al., 2010).

The low slip rates indicate long recurrence times for maximum (M 6-7) earthquakes (ca. 5,000 - 200,000 years), stressing the shortness of the historical record as well as the need to refine the geological (neotectonic/ paleoseismological) data. There is also a need to collect

Fig. 4.- Map of neotectonic vertical movements in mainland Portugal based upon uplift values inferred from raised marine terraces and the drainage network entrenchment, as explained in the text (adapted from Cabral, 1995). Movement accumulated approximately in the last $3 \mathrm{Ma}$; uplift isolines in hundreds of meters. Relief obtained from $200 \mathrm{~m}$ grid digital terrain model. This output should be envisaged as a rough approximation, particularly for the inland areas, where long term entrenchment may be considerably delayed relatively to the regional uplift.

Fig. 4.- Mapa de movimientos neotectónicos verticales en el Portugal continental basada en valores de levantamiento obtenidos en terrazas marinas y en valores de encajamiento de la red de drenaje (adaptado de Cabral, 1995, ver texto). El movimiento ha tenido lugar aproximadamente durante los últimos 3 Ma. Isolíneas del levantamiento en centenares de metros. Relieve obtenido del modelo digital del terreno con un paso de malla de $200 \mathrm{~m}$. Este resultado debería ser considerado como una aproximación, especialmente en lo que se refiere a las zonas lejos de la costa, donde el encajamiento de largo término podría estar considerablemente desfasado respecto del levantamiento regional. 

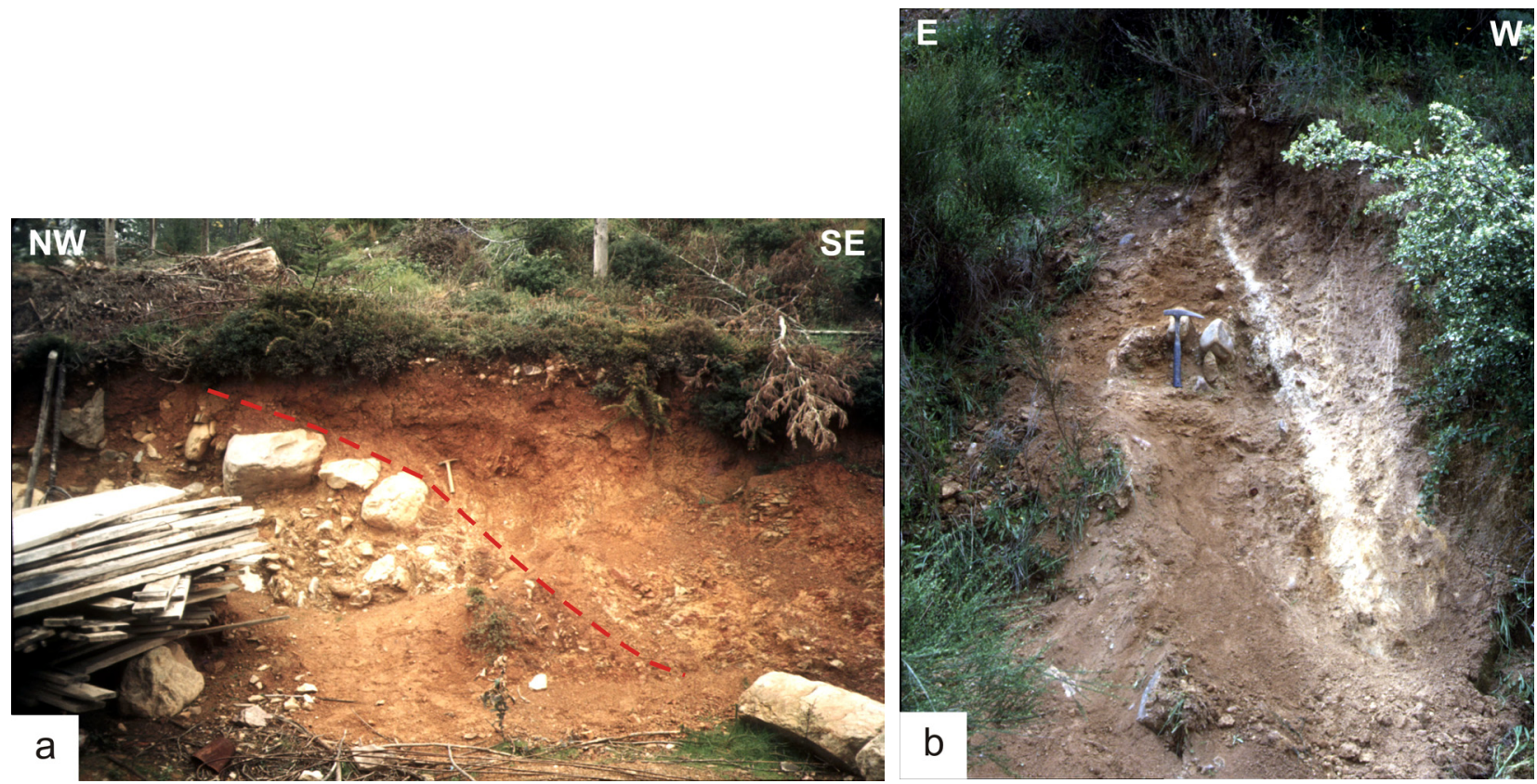

Fig. 5.- a - Outcrop of the Seia-Lousã reverse fault, at the N boundary of the Portuguese Central Cordillera (near Carvalhal), showing Cambrian schist (SE) thrusted over fan-conglomerates of probable Piacenzian age (?) (NW); b - Outcrop of the Manteigas-Vilariça-Bragança strike-slip fault near the Douro river (Pocinho), showing Variscan granite (W) in fault contact with river terrace deposits of probable Upper Pleistocene age $(200-100 \mathrm{ka})(\mathrm{E})$.

Fig. 5.- a - Afloramiento de la falla inversa de Seia-Lousã, en el límite septentrional de la cordillera central Portuguesa (cerca de Carvahal) que muestra esquistos Cámbricos cabalgando sobre conglomerados aluviales de probable edad Piaccenciana (NW); b - Afloramiento de la falla de Manteigas-Vilariça-Bragança cerca del río Duero (Pocinho) que muestra el granito varisco (Oeste) en contacto por falla con depósitos de terraza de probable edad pleistocena superior $(200-100 \mathrm{ka})$ (Este).

further archaeoseismological evidence, as a tool for detecting and characterizing past earthquakes.

In spite of the early paleoseismic studies performed at the Ferrel site (Cabral and Ribeiro, 1981), until the late 1990 's the neotectonic studies in mainland Portugal have favoured the regional coverage of faults that exhibit upper Pliocene to Quaternary activity, rather than conducting detailed research regarding the seismogenic behaviour of particular structures. The reason was to obtain a most complete database of active or potentially active structures.

However, the lack of paleoseismic data emerged as a major drawback, when knowledge of the most recent fault activity and earthquake potential was needed for specific seismic hazard evaluations. In order to obviate this problem, two research projects were submitted in 1998 for studying the seismic hazard in the Lower Tagus Valley (projects TAGUS, PI J. Fonseca, and SHELT, PI J. Cabral), which comprised a significant component of paleoseismological research. Paleoseismic results on the Lower Tagus fault system were published by Fonseca et al. (2000), Vilanova (2003) and Vilanova and Fonseca (2004), and these were contested and interpreted as having landslide origin by Cabral and Marques (2001) and Cabral et al. (2002, 2003, 2011a), while the palesoseismic research performed by the SHELT group yielded in- conclusive results (Cabral et al., 2011b).

Paleoseismological research in the Manteigas-VilariçaBragança fault was started by Rockwell and collaborators in 2004-05, in the scope of studies for the construction of two nearby dams (the Sabor river dams), and the results were published in 2009 (Rockwell et al., 2009). Several trenches were excavated at 3 sites and, according to those authors, the following evidence was found (from $\mathrm{N}$ to $\mathrm{S}$ ): at the Vilariça site, a fault was uncovered left-laterally displacing late Pleistocene channel deposits $(18 \mathrm{ka} / \sim 6.5$ $\mathrm{m}, 23 \mathrm{ka} / \sim 9 \mathrm{~m}$ ), evidencing a slip-rate of $0.3-0.5 \mathrm{~mm} /$ yr; at the Vale Meão site, the main fault in the Variscan basement rocks was found propagating into late Pleistocene sediments with small reverse offsets (strike-slip unknown), evidencing 2 (possibly 3 ?) events in the past $14.5 \mathrm{ka}$, yielding an average recurrence period of $\sim 5-7 \mathrm{ka}$. However, the 2 to 3 events appeared probably clustered between 14.5-11 ka, implying a recurrence period $<2 \mathrm{ka}$ during that period. A small offset rill located $2.2 \mathrm{~km}$ to the SSW suggested 2-2.5 m of left-lateral displacement in the last event. At the Longroiva site the study was inconclusive due to the lack of young sediments. The fault segment length and the observed strike-slip displacements argue for earthquakes in the $\mathrm{M} 7+$ range.

Two research projects were submitted in 2006 to further implement paleoseismic studies in mainland Portu- 
gal, namely project RETURN, coordinated by J. Fonseca, and project PALEOSISPOR, coordinated by $\mathrm{J}$. Cabral. Further investigations were performed on the Vilariça fault in the scope of PALEOSISPOR, and the results supported the recent activity at the Vale Meão site, pointing to strike-slip surface faulting affecting late Pleistocene fluvial terrace sediments (Cabral et al., 2010; Perea et al., 2010). Paleoseismic studies have also been performed on the NNE-SSW trending S.Teotónio-Aljezur-Sinceira strike-slip fault system, located near the SW coast, pointing to seismogenic activity during the Pleistocene (Figueiredo et al., 2008, 2009a,b, 2010a,b). Active tectonic studies also continued in the Lower Tagus valley region in the scope of project RETURN and of a new project submitted in 2009 (project FINDER, PI G. Besana-Ostman), resulting in the recognition of geomorphic expression of recent faulting in the area (BesanaOstman et al., 2010, 2012).

Albeit the efforts that have been undertaken in the past few years, the amount of paleoseismic data from faults in mainland Portugal is still very small and insufficient for adequately addressing regional seismic hazard assessment, stressing the need to perform further paleoseismic investigations and making this a priority issue.

Another critical subject for the refinement of the neotectonic data in Portugal pertains to the difficulty in dating the stratigraphical and geomorphological references used for characterizing the deformations, which frequently are beyond the limit of ${ }^{14} \mathrm{C}$, and even of optically stimulated luminescence (OSL) due the natural radiation high dose rates. Further implementation of OSL dating, and particularly the introduction of cosmogenic radionuclide dating $(\mathrm{CRN})$, is essential to surpass that limitation and to better characterize the timing of the neotectonic movements (uplift/subsidence and fault slip) and to estimate strain rates.

Finally, a network for continuous GPS monitoring of regional tectonic deformations should be established in mainland Portugal. Observations have already been performed in the Lower Tagus Valley and the Algarve (southern Portugal) regions, but consistent results have not yet been obtained. Monitoring areas should be enlarged in order to enclose major active structures, as the Penacova-Régua-Verin and the Vilariça faults, and the

Fig. 6.- Map of faults in mainland Portugal (onshore area) evidencing activity in the last $\sim 3 \mathrm{Ma}$; modified from Neotectonic Map of Mainland Portugal, 1:1,000,000 scale (Cabral and Ribeiro, 1988; Cabral, 1995).

Fig. 6.- Mapa de fallas en el Portugal continental (zona emergida) que pone en evidencia la presencia de actividad tectónica en los últimos 3 Ma; modificado del Mapa Neotectónico de Portugal Continental, a escala 1:1,000,000 (Cabral and Ribeiro, 1988, Cabral, 1995).
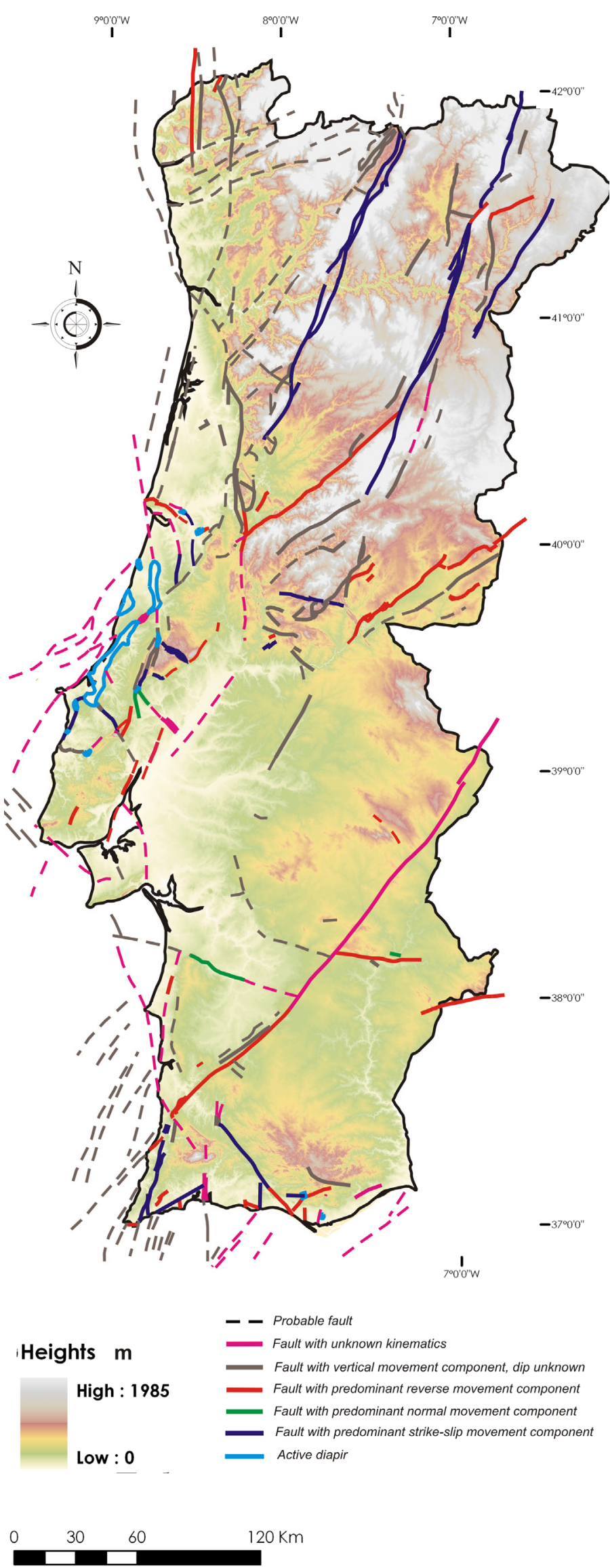
expected slow strain rates argue for the urgency in starting measurements, as it will take years to adequately characterize velocities.

\section{Acknowledgments}

We are grateful to Prof. Thomas Rockwell and an anonymous reviewer for their careful reviews and comments that significantly improved the manuscript.

\section{References}

Baptista, J.C., Cabral, J., Ribeiro, A. (1997): Evolução tectónica da zona de falha Penacova-Régua-Verin. In: C. Pires, M. Gomes e C. Coke (eds.), Comunicações da XIV Reunião de Geologia do Oeste Peninsular, Universidade de Trás-os-Montes e Alto Douro, Vila Real, p. 27-30.

Baptista, J.C. (1998): Estudo neotectónico da Zona de Falha Penacova-Régua-Verin. PhD thesis, Universidade de Trás-os-Montes e Alto Douro, Vila real: 346 p.

Baptista, J.C., Cabral, J., Ribeiro, A. (1998): Seismotectonics of Chaves and Moledo mineral springs in Penacova-Régua-Verin Fault Zone. Actas do V Congresso Nacional de Geologia (Resumos alargados), Comunicações do Instituto Geológico e Mineiro, 84- Fasc. I: D-69-D-72.

Baptista, M.A., Miranda, P.M.A., Chierici, F., Zitellini, N. (2003): New study of the 1755 earthquake source based on multi-channel seismic survey data and tsunami modeling. Natural Hazards and Earth Science Systems, 3: 333-340.

Barriga, F., Ribeiro, A., Cabral, J. (1988): Regional geology, tectonics and seismotectonics of the Aldeadavilla site (Zamora, Spain). Geonovas, 10: 1-5.

Besana-Ostman, G.M., Ferreira, H., Narciso. J., Falcão Flor, A.P., Pinheiro. P., Nemser, E., Villanova, S.P., Fonseca, J.D. (2010): The Lower Tagus Valley Fault Zone: results of recent mapping activities. In: J.M. Insua and F. Martín González (eds.), First Iberian Meeting on Active Faults and Paleoseismology, Sigüenza (Guadalajara, Espanha): 37-40.

Besana-Ostman, G.M., Villanova, S.P., Nemser, E.S., Falcão Flor, A.P., Heleno, S., Ferreira, H., Fonseca, J.D. (2012): Large Holocene Earthquakes in the Lower Tagus Valley Fault Zone, Central Portugal. Seismological Research Letters, 83(1): 67-76, doi: 10.1785/gssrl.83.1.67.

Bender, M.L., Fairbanks, R.G., Taylor, F.W., Matthews. R.K., Goddard, J.G., Broecker, W.S. (1979): Uranium-series dating of the Pleistocene reef tracts of Barbados. West Indies. Geol. Soc. Am. Bull., 90: 577- 594.

Bensaúde, A. (1910): Le Tremblement de Terre de la Vallée du Tage du 23 Avril 1909 (Note préliminaire). Bull. Soc. Port. Sc. Nat., t. III: 89-129.

Birot, P. (1945): Sur la morphologie de Trás-os-Montes. Bull. de l'Assoc. de Geog. Français, n. 173-174: 108-120.

Birot, P. (1949): Les Surfaces d'Erosion du Portugal Central et Septentrional. Rapport Comm. Cart. Surf. Aplan. U.G.I., XVI Congrés International de Géographie, Lisbonne, 1949: 116 p.

Bloom, A.L., Broecker, V.S., Chappell, J.M.A., Matthews, R.K., Mesolella, K.J. (1974): Quaternary sea level fluctuations on a tectonic coast: new Th-U dates from the Huon Peninsula, New Guinea. Quaternary Research, 4: 185-205. doi: 10.1016/00335894(74)90007-6

Bloom, A.L. (1980): Late Quaternary sea level change on south Pa- cific coasts: a study in tectonic diversity. In: N.A. Morner (ed.). Earth Rheology, Isostasy and Eustasy. Wiley, Chichester: 505- 516.

Borges, J.F., Fitas, A.J.S., Bezzeghoud, M., Teves-Costa, P. (2001): Seismotectonics of Portugal and its adjacent Atlantic area. Tectonophysics, 337: 373-387.

Brum da Silveira, A. (2002): Neotectónica e Sismotectónica de um Sector do Alentejo Oriental. $\mathrm{PhD}$ thesis, Universidade de Lisboa: $339 \mathrm{p}$.

Brum da Silveira, A., Cabral, J., Perea, H., Ribeiro, A. (2009): Evidence for coupled reverse and normal active faulting in $\mathrm{W}$ Iberia. The Vidigueira-Moura and Alqueva faults (SE Portugal). Tectonophysics, 474: 184-199, doi: 10.1016/j.tecto.2009.04.013.

Burbank, D., Anderson, R.S. (2001): Tectonic Geomorphology. Blackwell Science, Malden: 274p.

Cabral, J. (1981): Levantamento Geológico Pormenorizado (Escala 1:2.000) de Uma Área a NE de Ferrel (Peniche). GPSN, Doc. 1R81014, Dossier "Licenciamento Ferrel”, 97 p., 12 folhas de 1 mapa na escala 1:2.000. (Internal Report).

Cabral, J., Ribeiro, A. (1981): Levantamento geológico de uma sanja aberta em Vale de Janelas (Ferrel), para estudo da actividade da zona de falha de Ferrel. GPSN, Documento 1R81001, Dossier "Licenciamento de Ferrel", $11 \mathrm{p}$.

Cabral, J., Dias, R.P., Brum, A. (1984): Estudo de falhas afectando formaçoes plio-quaternárias na zona da Fonte da Telha (Península de Setúbal). Comun. Serv. Geol. de Portugal, 70(1): 83-91.

Cabral, J. (1985): Estudos de Neotectónica em Trás-os-Montes Oriental. Dissertação apresentada em provas de aptidão pedagógica e capacidade cientifica. Dep. Geologia, Fac. Ciências Lisboa: 124 p., 1 mapa na escala 1:25.000.

Cabral, J., Ribeiro, A. (1986): Evidências de actividade neotectónica na falha de Ferrel (Peniche). Resumos, II Congresso Nacional de Geologia, Lisboa, Maleo, 2(13): p. 14.

Cabral, J., Ribeiro, A. (1988): Carta Neotectónica de Portugal Continental, Escala 1:1.000.000. Dep. Geol. Fac. Ciênc. Lisboa, Serv. Geol. Portugal, Gab. Prot. Seg. Nuclear, editada pelos Serv. Geol. Portugal, Lisboa.

Cabral, J. (1989): An example of intraplate neotectonic activity, Vilariça basin, Northeast Portugal. Tectonics, 8(2): 285-303.

Cabral, J., Ribeiro, A. (1989): Carta Neotectónica de Portugal Continental, Escala 1:1.000.000. Nota explicativa. Serv. Geol. Portugal, Lisboa, $10 \mathrm{p}$.

Cabral, J. (1993): Neotectónica de Portugal Continental. PhD thesis, Universidade de Lisboa: $435 \mathrm{p}$.

Cabral, J. (1995): Neotectónica em Portugal Continental. Memórias do Instituto Geológico e Mineiro, 31, Lisboa: 265 p.

Cabral, J., Marques, F. (2001): Paleoseismological studies in Portugal: Holocene thrusting or landslide activity? EOS Transactions, 82: 351-352. doi: 10.1029/01EO00221

Cabral, J., Marques, F., Figueiredo, P. (2002): Paleoseismicity evidence in the Lower Tagus Valley (Lisbon Region)? An example of misinterpretation of geological data. $3^{a}$ Assembleia Luso-Espanhola de Geodesia e Geofísica, Proceedings I Univ. Polit. de Valencia,: 386-389.

Cabral, J., Marques, F., Figueiredo, P., Simão, N., Matias, L. (2003): New data on the active surface faulting vs. landsliding controversy concerning the Vila Chã de Ourique site (Lower Tagus Valley). Ciências da Terra N. Esp. 5, VI Congresso Nacional de Geologia, Caparica, D10-D13 (CD-ROM).

Cabral, J., Moniz, C., Ribeiro, P., Terrinha, P., Matias, L. (2003): Analysis of seismic reflection data as a tool for the seismotectonic assessment of a low activity intraplate basin - the Lower Tagus Valley (Portugal). Journal of Seismology,7: 431-447. doi: 10.1023/B: JOSE.0000005722.23106.8d. 
Cabral, J., Ribeiro, P., Figueiredo, P., Pimentel, N., Martins, A. (2004): The Azambuja fault: An active structure located in an intraplate basin with significant seismicity (Lower Tagus Valley, Portugal). Journal of Seismology, 8: 347-362.

Cabral, J., Perea, H., Figueiredo, P.M., Besana-Ostman, G., Brum da Silveira, A., Cunha, P.P., Gomes, A., Lopes, F.C., Pereira, D., Rockwell, T. (2010): Preliminary results of a paleoseismological study of the Vilariça fault (NE Portugal). In: J. M. Insua and F. Martín González (eds.),Contribución de la Geología al Análisis de la Peligrosidad Sísmica, , Livro de Resumos da $1^{\text {a }}$ Reunião Ibérica sobre Falhas Activas e Paleossismologia, : 41-44.

Cabral, J., Marques, F., Figueiredo, P., Matias, L. (2011a): Active surface faulting or landsliding in the Lower Tagus Valley (Portugal)? A solved controversy concerning the Vila Chã de Ourique site. Journal of Seismology, 15: 215-234. doi:10.1007/s10950-0109221-8.

Cabral, J., Moniz, C., Batlló, J., Figueiredo, P., Carvalho, J., Matias, L., Teves-Costa, P., Dias, R., Simão, N. (2011b): The 1909 Benavente (Portugal) earthquake: search for the source. Natural Hazards, 20 December 2011, 1-17. doi:10.1007/s11069-011-0062-8.

Carvalho, J., Cabral, J., Gonçalves, R., Torres, L., Mendes-Victor, L. (2006): Geophysical methods applied to fault characterization and earthquake potential assessment in the Lower Tagus Valley, Portugal. Tectonophysics, 418: 277-297. doi: 10.1016/j.tecto.2006.02.010.

Carvalho, J., Rabeh, T., Cabral, J., Carrilho, F., Miranda, J.M. (2008): Geophysical characterization of the Ota-Vila Franca de Xira-Lisbon-Sesimbra fault zone, Portugal. Geophys. J. Int., 174: 567-584. doi: 10.1111/j.1365-246X.2008.03791.x.

Chappell, J. (1974): Geology of coral terraces, Huon Peninsula, New Guinea: a study of Quaternary tectonic movements and sea Level changes. Geol Soc. Am. Bull., 85: 553-570.

Chappell, J., Shackleton, N.J. (1986): Oxygen isotopes and sea level. Nature, 324: 137-140. doi:10.1038/324137a0

Choffat, P. (1904): Les Tremblements de Terre de 1903 en Portugal. Comissão do Serviço Geológico de Portugal, 5: 279-306.

Choffat, P. (1908): Essai sur la tectonique de la chaîne de l'Arrabida. Comissão do Serviço Geológico de Portugal, Imprensa Nacional, Lisboa: 89 p.

Choffat, P., Bensaúde, A. (1911): Études sur le Séisme du Ribatejo du 23 Avril de 1909. Comm. Serv. Geol. du Portugal, Lisboa: 140 p.

Cunha, P.P., Pereira, D.I. (2000): Cenozoic evolution of the Longroiva-Vilariça area (NE Portugal). Ciências da Terra (UNL) 14: 89198.

Cunha, P.P., Pimentel, N., Pereira D.I. (2000): Sedimentary and tectonic signature of the betic compression climax in Portugal. The late Vallesian-Turolian sedimentary discontinuity. Ciências da Terra (UNL) 14: 61-72.

Cunha, P.P., Martins, A.A., Daveau, S., Friend, P.F. (2005): Tectonic control of the Tejo river fluvial incision during the late Cenozoic, in Ródão - central Portugal (Atlantic Iberian border). Geomorphology, 64: 271-298. doi: 10.1016/j.geomorph. 2004.07.004

Cunha, P., Martins, A., Huot, S., Murray, A., Raposo, L. (2008): Dating the Tejo River lower terraces (Ródão, Portugal) to assess the role of tectonics and uplift. Geomorphology, 102: 43-54. doi:10.1016/j.geomorph.2007.05.019.

Cunha, P.P., Pais, J., Legoinha, P. (2009): Geologic evolution of the Portugal mainland during the Cenozoic - alluvial and marine sedimentation at a passive continental margin (W Iberia). In: G. Rodríguez, J. Gallastegui, G. Flor Blanco, J. Martín Llaneza (eds.), 6th Symposium on the Atlantic Iberian Margin, Universidad de Oviedo, Oviedo: xi-xx.

Cunha, P.P., Lopes, F.C., Gomes, A., Pereira, D.I., Cabral, J., De Vicente, G., Martins, A.A. (2010): The fluvial terraces of the Douro
River as indicators of tectonic displacements and of crustal uplift (Pocinho area, Vilariça fault zone). In: J. M. Insua and F. Martín González (eds.), Contribución de la Geología al Análisis de la Peligrosidad Sísmica, , Livro de Resumos da $1^{\text {a }}$ Reunião Ibérica sobre Falhas Activas e Paleossismologia, Sigüenza: 45-48.

DeMets, C., Gordon, R.G., Argus, D.F., Stein, S. (1990): Current plate motion. Geophys. J. Int., 101: 425-478.

DeMets, C., Gordon, R.G., Argus, D.F., Stein, S. (1994): Effect of recent revisions to the geomagnetic reversal timescale. Geophysical Research Letters, 21: 2191-2194.

DeMets, C., Gordon, R.G., Argus, D.F. (2010): Geologically current plate motions. Geophys. J. Int., 181: 1-80. doi:10.1111/j.1365246X.2009.04491.x.

Dias, R.P., Cabral, J. (1989): Neogene and Quaternary reactivation of the Ponsul fault in Portugal. Comun. Serv. Geol. Portugal, 75: 3-28.

Dias, R.P. (2001): Neotectónica da Região do Algarve. $\mathrm{PhD}$ thesis, Universidade de Lisboa, $369 \mathrm{p}$.

Dias, R.P., Cabral, J. (2002a): Interpretation of recent structures in an area of cryptokarst evolution - neotectonic versus subsidence genesis. Geodinamica Acta, 15(4): 233-248.

Dias, R.P., Cabral, J. (2002b): Actividade neotectónica na região do Algarve (S de Portugal). Comun. Inst. Geol. e Mineiro, 89: 193208.

Dineva, S., Batlló, J., Mihailov, J.D., Van Eck, T. (2002): Source parameters of four strong earthquakes in Bulgaria and Portugal at the beginning of the 20th century. Journal of Seismololgy, 6: 99-123.

Dinis, J.O.F. (1910): Contribuição para o estudo dos tremores de Terra em Portugal: o abalo sísmico de 23 de Abril de 1909. Sep. da Revista de Obras Públicas, $n^{\circ} 483$ e 484, Imprensa Nacional, Lisboa: 59 p.

Dinis, P.A. (2004): Evolução pliocénica e quaternária do vale do Cértima. PhD thesis, Universidade de Coimbra: $351 \mathrm{p}$.

Dinis, P.A., Cabral, J., Soares, A.F. (2007): Genesis of deformation structures affecting Plio-Pleistocene sediments in the western Portuguese mainland (West Iberia). Implication on the regional neotectonics. Geodinamica Acta, 20/6: 415-431. doi:10.3166/ga.20.

Dowsett, H.J., Cronin, T.M. (1990): High eustatic sea level during the middle Pliocene: Evidence from the Southeastern U.S. Atlantic Coastal Plain. Geology, 18: 435-438. doi: 10.1130/00917613(1990)018<0435:HESLDT>2.3.CO;2

Feio, M. (1949): A Serra de Portel. Bol. Soc. Geol. Portugal, vol. VIII: 101-106.

Feio, M. (1951a): A evolução do relevo do Baixo Alentejo e Algarve. Com. Serv. Geol. Portugal, t. XXXII, $2^{\mathrm{a}}$ parte: 303-447.

Feio, M. (1951b): Notas geomorfológicas. A depressão de RéguaVerin. Com. Serv. Geol. Portugal, t. XXXII, 1ª parte: 181-222.

Fernandes, R.M.S., Ambrosius, B.A.C., Noomen, R., Bastos, L., Wortel, M.J.R., Spakman, W., Govers, R. (2003): The relative motion between Africa and Eurasia as derived from ITRF2000 and GPS data. Geophysical Research Letters, 30(16): 1828. doi:10.1029/2003GL017089.

Figueiredo, P.M., Cabral, J., Rockwell, T., Dias, R. (2008): Late Pliocene to Pleistocene tectonic activity in SW Portugal: The S. Teotónio-Aljezur-Sinceira fault system - a review. YORSGET, International Meeting of Young Researchers in Structural Geology and Tectonics, Oviedo: 505-508.

Figueiredo, P.M., Cabral, J., Rockwell, T. (2009a): Actividade tectónica plistocénica no SW de Portugal: o sistema de falhas S. Teotónio-Aljezur-Sinceira e evidências de levantamento ao longo do litoral. In: Boski, T., Moura, D., Gomes, A. (eds.), Livro de Resumos, VII Reunião do Quaternário Ibérico, Universidade do Algarve, Faro: 240-243.

Figueiredo, P.M., Cabral, J., Rockwell, T. (2009b): Actividade tectó- 
nica plistocénica no SO de Portugal: novos dados adquiridos por observações de campo e trincheiras. In: G. Rodríguez, J. Gallastegui, G. Flor Blanco, J. Martín Llaneza (eds.), $6{ }^{\circ}$ Simpósio sobre a Margem Ibérica Atlântica, Universidade de Oviedo, Oviedo: 1-4.

Figueiredo, P.M., Cabral, J., Rockwell, T. (2010a): Southwest Portugal Plio-Pleistocene tectonic activity studies: the S.TeotónioAljezur-Sinceira fault system and coastal tectonic uplift evidences. In: J. M. Insua and F. Martín González (eds.), Contribución de la Geología al Análisis de la Peligrosidad Sísmica, Livro de Resumos da $1^{\text {a }}$ Reunião Ibérica sobre Falhas Activas e Paleossismologia, Sigüenza: 49-52.

Figueiredo, P.M., Cabral, J., Rockwell, T. (2010b): Neotectonics and paleoseismic studies at SW Portugal mainland: The S. Teotónio - Aljezur - Sinceira Fault System. Actas do VIII Congresso Nacional de Geologia, e-Terra, Geosciences, 11(8): 4 p. On-line Journal, http://e-terra.geopor.pt,

Figueiredo, P. M., Cabral, J., Rockwell, T. K. (2011): Plio- PLeistocene Tectonic Activity in the Southwest of Portugal. In: C. Grützner, R. Pérez-López, T. Fernández-Steeger, I. Papanikolaou, K. Reicherter, P.G. Silva and A. Vött (eds.), 2nd INQUA-IGCP 567 International Workshop Proccedings, Vol. 2: Earthquake Geology and Archaeology: Science, Society and Critical facilities: 30-33.

Fonseca, F.B.D., Bosi, V., Vilanova, S.P., Meghraoui, M. (2000): Investigations unveil Holocene thrusting for onshore Portugal. EOS Transactions, 81: 412-413.

Freire de Andrade, C.B. (1933): A tectónica do estuário do Tejo e dos vales submarinos ao largo da costa da Caparica, e a sua relação com as nascentes termo-medicinais de Lisboa. Com. Serv. Geol. Portugal, 19: 23-40.

Freire de Andrade, C.B. (1937): Os vales submarinos portugueses e o diastrofismo das Berlengas e da Estremadura. Mem. Serv. Geol. de Portugal, 7: 249 p.

Fukao, Y. (1973): Thrust faulting at a lithospheric plate boundary. The Portugal earthquake of 1969. Earth and Planetary Science Letters, 18: 205-216.

García-Mayordomo, J., Insua-Arévalo, J.M., Martínez-Díaz, J.J., Jiménez-Díaz, A., Álvarez-Gómez, J.A., Pérez-López, R., Rodríguez-Pascua, M.A., Martín-González, F., Giner-Robles, J., Masana, E., Nemser, E.S., Cabral, J. (2010): Active Faults Database of Iberia (First Stage): Objectives and Preliminary Structure. In: J. M. Insua and F. Martín González (eds.), Contribución de la Geología al Análisis de la Peligrosidad Sísmica, , Livro de Resumos da $1^{\mathrm{a}}$ Reunião Ibérica sobre Falhas Activas e Paleossismologia, Sigüenza: 189-192.

Gomes, A.A.T. (2008): Evolução Geomorfológica da Plataforma Litoral entre Espinho e Águeda. PhD thesis, Universidade do Porto: $339 \mathrm{p}$.

Gràcia, E., Dañobeitia, J., Vergés, J., and the PARSIFAL Team (2003): Mapping active faults offshore Portugal $\left(36^{\circ} \mathrm{N}-38^{\circ} \mathrm{N}\right)$ : Implications for seismic hazard assessment along the southwest Iberian margin. Geology, 31(1): 83-86. doi: 10.1130/0091-7613(2003 )031

Gutscher, M.A., Malod, J., Rehault, J.P., Contrucci, I., Klingelhoefer, F., Mendes-Victor, L., Spakman, W. (2002): Evidence for active subduction beneath Gibraltar. Geology, 30: 1071-1074. doi: doi:10.1130/0091-7613(2002)030<1071:EFASBG >2.0.CO;2

Gutscher, M.A. (2004): What caused the great Lisbon earthquake? Science, 305: 1247-1248. doi: 10.1126/science.1101351

Gutscher, M.A., Dominguez, S., Westbrook, G.K., Leroy, P. (2009): Deep structure, recent deformation and analog modeling of the Gulf of Cadiz accretionary wedge: Implications for the 1755 Lisbon earthquake. Tectonophysics, 475: 85-97. doi:10.1016/j.tecto.2008.11.031.

Hancock, G.S., Anderson, R.S. (2002): Numerical modeling of fluvial strath-terrace formation in response to oscillating climate. Geol.
Soc. Am. Bulletin, 114(9): 1131-1142.

Haq, B.V., Hardenbol, J., Vail, P.R. (1987): Chronology of fluctuating sea levels since the Triassic. Science, 235: 1156-1167. doi: 10.1126/science.235.4793.1156

Johnston, A.C., Kanter, L.R. (1990): Earthquakes in stable continental crust. Scientific American, 262(3): 42-49.

Johnston, A. (1996): Seismic moment assessment of earthquakes in stable continental regions - III. New Madrid, 1811-1812, Charleston 1886 and Lisbon 1755. Geophys. J. Int., 126: 314-344.

Maríinez-Solares, J.M., López Arroyo, A. (2004): The great historical 1755 earthquake: effects and damage in Spain. Journal of Seismololgy, 8: 275-294.

Martins, A.A., Cunha, P.P., Huotc, S., Murray, A.S., Buylaertc, J.P. (2009): Geomorphological correlation of the tectonically displaced Tejo River terraces (Gavião-Chamusca area, central Portugal) supported by luminescence dating. Quaternary International, 199: 75-91. doi:10.1016/j.quaint.2009.01.009.

Merritts, D.J., Vincent, K.R., Wohl, E.E. (1994): Long river profiles, tectonism, and eustasy; a guide to interpreting fluvial terraces. Journal of Geophysical Research, 99 (B7): 14,031-14,050.

Naish, T.R. and Wilson, G. (2009): Constraints on the amplitude of Mid-Pliocene (3.6-2.4 Ma) eustatic sea-level fluctuations from the New Zealand shallow-marine sediment record. Phil. Trans. R. Soc., A. 367: 169-187. doi:10.1098/rsta.2008.0223.

Nemser, E.S., García-Mayordomo, J., Cabral, J., Fonseca, J.F.B.D., Martínez-Díaz, J.J., Vilanova, S., and the 2010 Working Group on Iberian Seismogenic Sources (2010): Compilation of parameterized seismogenic sources in Iberia for the SHARE European-scale seismic source model. In: J. M. Insua and F. Martín González (eds.) Contribución de la Geología al Análisis de la Peligrosidad Sísmi$c a$, Livro de Resumos da $1^{\text {a }}$ Reunião Ibérica sobre Falhas Activas e Paleossismologia, Sigüenza: 201-204.

Nocquet, J.M, Calais, E. (2004): Geodetic Measurements of Crustal Deformation in the Western Mediterranean and Europe. Pure Appl. Geophys., 161: 661-681. doi:10.1007/s00024-003-2468-z.

Pedrera, A., Ruiz-Constán, A., Galindo-Zaldívar, J., Chalouan, A., Sanz de Galdeano, C., Marín-Lechado, C., Ruano, P., Benmakhlouf, M., Akil, M., López-Garrido, A.C., Chabli, A., Ahmamou, M., González-Castillo, L. (2011): Is there an active subduction beneath the Gibraltar orogenic arc? Constraints from Pliocene to presentday stress field. Journal of Geodynamics, 52: 83-96. doi:10.1016/j. jog.2010.12.003.

Perea, H., Cabral, J., Figueiredo, P.M., Besana-Ostman, G., Brum da Silveira, A., Cunha, P.P., Gomes, A., Lopes, F.C., Pereira, D., Rockwell, T. (2010): Quaternary seismic activity of the Vilariça fault (NE Portugal): Preliminary results of a paleoseismological study. Actas do VIII Congresso Nacional de Geologia, e-Terra, Geosciences, 11 (6): 4 p. On-line Journal, http://e-terra.geopor.pt, ISSN 1645-0388.

Pereira de Sousa, F.L. (1919-1932): O Terramoto do $1^{\circ}$ de Novembro de 1755 em Portugal e um Estudo Demográfico. Serviços Geológicos, 4 vols, Lisboa.

Ramos Pereira, A., Neves, M., Trindade, J., Borges, B., Angelucci, D.E., Monge Soares, A. (2007): Carbonate dunes and related deposits in Estremadura (Portugal). Sea-level changes and neotectonics. Publicações da Associação Portuguesa de Geomorfólogos, $\mathrm{V}: 165-178$

Raymo, M.E., Mitrovica, J.X., O’Leary, M.J., DeConto, R.M., Hearty, P.J. (2011): Departures from eustasy in Pliocene sea-level records. Nature Geoscience, 4: 328-332. doi:10.1038/NGEO1118.

Ribeiro, A. (1974): Contribution à l'Étude de Trás-os-Montes Oriental. Mem. Ser. Geol. Portugal, 24, Lisboa: 168 p.

Ribeiro, A. (2002): Soft Plate and Impact Tectonics. Springer, Berlin, $324 \mathrm{p}$. 
Ribeiro, A., Almeida, F.M. (1981): Geotermia de baixa entalpia em Portugal continental. Geonovas, 1(2): 60-71.

Ribeiro, A., Antunes, M.T., Ferreira, M.P., Rocha, P.B., Soares, A.F., Zbyszewski, G., Almeida, F. Moitinho de, Carvalho, D., Monteiro, J.H. (1979): Introduction à la Géologie Genérale du Portugal. Serv. Geol. Portugal, Lisboa, 114 p.

Ribeiro, A., Cabral, J., Baptista, R., Matias, L. (1996): Stress pattern in Portugal Mainland and the adjacent Atlantic region, West Iberia. Tectonics, 15(2): 641-659.

Ribeiro, A., Kullberg, M.C., Kullberg, J.C., Manuppella, G., Phipps, S. (1990): A review of Alpine tectonics in Portugal: Foreland detachment in basement and cover rocks. Tectonophysics, 184: 357366.

Ribeiro, O. (1942): Notas sobre a evolução morfológica da orla meridional da Cordilheira Central entre Sobreira Formosa e a fronteira. Bol. Soc. Geol. Portugal, v. I, fasc. III: 123- 145.

Ribeiro, O. (1943): Evolução da falha do Ponsul. Com. Serv. Geol. Portugal, t. XXIV: 109-123.

Ribeiro, O. (1949): Le Portugal Central (Livret-Guide de l'Excursion C). XVI Congrés International de Géographie, Lisbonne, 1949 (1982, Réimpression de la première édition), 180 p.

Ribeiro, O. (1951): Três notas de geomorfologia da Beira-Baixa. Com. Serv. Geol. Portugal, 32: 271-294.

Rockwell, T., Fonseca, J., Madden, C., Dawson, T., Owen, L.A., Vilanova, S., Figueiredo, P. (2009): Paleoseismology of the Vilariça Segment of the Manteigas-Bragança Fault in Northeastern Portugal. In: Reicherter, K., Michetti, A.M., Silva, P. G. (eds.) Palaeoseismology: Historical and Prehistorical Records of Earthquake Ground Effects for Seismic Hazard Assessment. Geol. Soc. London, Special Publications, 316: 237-258. doi: 10.1144/SP316.15.

Rosas, F.M., Duarte, J.C., Terrinha, P., Valadares, V., Matias, L. (2009): Morphotectonic characterization of major bathymetric lineaments in Gulf of Cadiz (Africa-Iberia plate boundary): Insights from analogue modelling experiments. Marine Geology, 261: 3347. doi:10.1016/j.margeo.2008.08.002.

Sequeira, A., Cunha, P.P., Sousa, M.B. (1997): A reactivação de falhas, no intenso contexto compressivo desde meados do Tortoniano, na região de Espinhal-Coja-Caramulo (Portugal Central). Comun. Inst. Geol. e Mineiro, 83: 95-126.

Serpelloni, E., Vannucci, G., Pondrelli, S., Argnani, A., Casula, G., Anzidei, M., Baldi, P., Gasperini, P. (2007): Kinematics of theWestern Africa-Eurasia plate boundary from focal mechanisms and GPS data. Geophys. J. Int., 169: 1180-1200. doi:10.1111/j.1365246X.2007.03367.x.

Shackleton, N.J., Opdyke, N.D. (1973): Oxygen isotope and paleomagnetic stratigraphy of equatorial Pacific core V28-239, late Pliocene to latest Pleistocene. Geological Society of America Mem., 145: 449-464.

Shackleton, N.J., Backman, J., Zimmerman, H., Kent, D.V., Hall, M.A., Roberts, D.G., Schuitker, D., Baldauf, J.G., Desprairies, A., Homrighausen, R., Huddlestun, P., Keene, J.B,; Kaltenback, A.J., Krumsiek, K.A.O., Morton, A.C., Murray, J.W., Westberg-Smith, J. (1984): Oxygen isotope calibration of the onset of ice-rafting and history of glaciation in the North Atlantic region. Nature, 307: 620-623. doi:10.1038/307620a0

Siddall, M., Chappell, J., Potter E.-K. (2006): Eustatic Sea Level During Past Interglacials. In: F. Sirocko, T. Litt, M. Claussen, M.F. Sanchez Goni (eds.) The Climate of Past Interglacials, , Elsevier, Amsterdam: 75-92.

Silva, I., Cruz, I., Gomes, J., Costa, A., Almeida, P., Cabral, J., Taborda, R., Caranova R., Laiginhas, C., Angelucci, D., Carrilho, F., Matias, L. (2008): GIS Seismotectonic database for mainland Portugal. ESIG 2008 - $10^{\circ}$ Encontro de Utilizadores de Informação
Geográfica, Oeiras: p. 10.

Stich, D., Batlló, J., Macià, R., Teves-Costa, P., Morales, J. (2005): Moment tensor inversion with single-component historical seismograms: The 1909 Benavente (Portugal) and Lambesc (France) earthquakes. Geophys. J. Int., 162: 850-858, doi: 10.1111/j.1365246X.2005.02680.x.

Teixeira, C. (1944): Tectónica plio-pleistocénica do Noroeste peninsular. Bol. Soc. Geol. Portugal, Porto, v. IV: 19-42.

Terrinha, P., Pinheiro, L.M., Henriet, J.-P., Matias, L., Ivanov, M.K., Monteiro, J.H., Akhmetzhanov, A., Volkonskaya, A., Cunha, T., Shaskin, P., Rovere, M. (2003): Tsunamigenic-seismogenic structures, neotectonics, sedimentary processes and slope instability on the southwest Portuguese Margin. Marine Geology, 195: 55-73, doi:10.1016/S0025-3227(02)00682-5.

Teves-Costa, P., Batlló J. (2011): The 23 April 1909 Benavente earthquake (Portugal): macroseismic field revision. Journal of Seismology, 15(1): 59-70, doi:10.1007/s10950-010-9207-6.

Teves-Costa, P., Rio, I., Marreiros, C., Ribeiro, R., Borges, J.F. (1999): Source Parameters of old earthquakes: Semi-automatic digitalization of analog records and seismic moment assessment. Natural Hazards, 19: 205-220.

United States Nuclear Regulatory Commission - USNRC (1978): Reactor Site Criteria. Rules and Regulations, Title 10, Chapter 1, Code of Federal Regulations-Energy, Part 100, 100.1- -100.7.

Vilanova SP (2003): Sismicidade e Perigosidade Sísmica do Vale Inferior do Tejo. PhD thesis, Instituto Superior Técnico, Lisboa: 259 p.

Vilanova SP, Fonseca JFBD (2004): Seismic hazard impact of the Lower Tagus Valley Fault Zone (SW Iberia). Journal of Seismology, 8: 331-345.

Zbyszewski, G. (1943): La Classification du Paléolithique Ancien et la Chronologie du Quaternarie de Portugal en 1942. Bol. Soc. Geol. de Portugal, v. II, fasc. 2-3: 113 p.

Zbyszewski, G. (1948): Note sur l'existence au Portugal d'une tectonique salifère pliocène. Las Ciencias, Madrid, Año XIII, n. I.

Zbyszewski, G. (1957): Le Quaternaire du Portugal. Bol. Soc. Geol. de Portugal, v. XIII, f. I-II: 227 p.

Zbyszewski, G. (1959): Étude Structural de la Vallée Typhonique de Caldas da Rainha (Portugal). Mem. Serv. Geol. Portugal, 3 (N.S.): $184 \mathrm{p}$.

Zitellini, N., Chierici, F., Sartori, R., Torelli, L. (1999): The tectonic source of the 1755 Lisbon earthquake and tsunami. Annali di Geofisica, 42(1): 49-55.

Zitellini, N., Gràcia, E., Matias, L., Terrinha, P., Abreu, M.A., DeAlteriis, G., Henriet, J.P., Dañobeitia, J.J., Masson, D.G., Mulder, T., Ramella, R., Somoza, L., Diez, S. (2009): The quest for the Africa-Eurasia plate boundary west of the Strait of Gibraltar. Earth and Planetary Science Letters, 280: 13-50, doi:10.1016/j. eps1.2008.12.005.

Zitellini, N., Mendes, L.A., Cordoba, D., Danobeitia, J., Nicolich, R., Pellis, G., Ribeiro, A., Sartori, R., Torelli, L., Bartolomé, R., Bortoluzzi, G., Calafato, A., Carrilho, F., Casoni, L., Chierici, F., Corela, C., Correggiari, A., Della Vedova, B., Gracia, E., Jornet, P., Landuzzi, M., Ligi, M., Magagnoli, A., Marozzi, G., Matias, L., Penitenti, D., Rodriguez, P., Rovere, M., Terrinha, P., Vigliotti, L., Zahinos-Ruiz, A. (2001): Source of 1755 Lisbon Earthquake and Tsunami Investigated. EOS, Transactions, Am Geophys. Union, 82(26): 285-282.

Zitellini, N., Rovere, M., Terrinha, P., Chierici, F., Matias, L., Ribeiro, A., and BIGSETS Team (2004): Neogene Through Quaternary Tectonic Reactivation of SW Iberian Passive Margin. Pure appl. Geophys., 161: 565-587, doi:10.1007/s00024-003-2463-4. 